\title{
PROFITABILITAS, LEVERAGE, KOMPOSISI DEWAN KOMISARIS, KOMITE AUDIT, DAN KOMPENSASI RUGI FISKAL TERHADAP PENGHINDARAN PAJAK PADA PERUSAHAAN PERBANKAN
}

\author{
DEWI PUTRININGSIH \\ EKO SUYONO \\ ELIADA HERWIYANTI \\ Fakultas Ekonomi dan Bisnis Universitas Jenderal Soedriman \\ eky075@unsoed.ac.id
}

\begin{abstract}
Tax avoidance has been a main concern of almost in the world. It is mostly done by tax payer due to its legality. This study aims to analyze factors affecting tax avoidance (i.e, profitability, leverage, independent bord, audit committee, and fiscal loss compensation) with firm size as a control variable. Implementing purposive sampling approach, this study ended-up with 30 companies for 2011-2015 period (i.e., 150 observations). By using OLS regression, the findings shows that profitability influences positively on tax avoidance, meanwhile, leverage and fiscal loss compensation affect negatively on tax avoidance. Moreover, corporate governace mechanisms (i.e., independent board and audit committee) and firm size as a control variable do not have a significant influence on tax avoidance. Therefore, this study contribute to providing empirical evidence on factors affecting tax avoidance in Indonesian banking companies.
\end{abstract}

Keywords: Profitability, leverage, independent bord, audit committee, fiscal loss compensation, tax avoidance

\begin{abstract}
Abstrak: Penghindaran pajak telah menjadi perhatian utama hampir di dunia. Hal ini sebagian besar dilakukan oleh wajib pajak karena legalitasnya. Penelitian ini bertujuan untuk menganalisis faktor-faktor yang mempengaruhi penghindaran pajak (yaitu, profitabilitas, leverage, batas independen, komite audit, dan kompensasi kerugian fiskal) dengan ukuran perusahaan sebagai variabel kontrol. Menerapkan pendekatan purposive sampling, penelitian ini berakhir dengan 30 perusahaan untuk periode 2011-2015 (mis., 150 pengamatan). Dengan menggunakan regresi OLS, temuan menunjukkan bahwa profitabilitas memengaruhi secara positif pada penghindaran pajak, sementara itu, leverage dan kompensasi kerugian fiskal berpengaruh negatif pada penghindaran pajak. Selain itu, mekanisme corporate governance (yaitu, dewan independen dan komite audit) dan ukuran perusahaan sebagai variabel kontrol tidak memiliki pengaruh yang signifikan terhadap penghindaran pajak. Oleh karena itu, penelitian ini berkontribusi untuk memberikan bukti empiris tentang faktor-faktor yang mempengaruhi penghindaran pajak di perusahaan perbankan Indonesia.
\end{abstract}

Kata kunci: Profitabilitas, leverage, batas independen, komite audit, kompensasi kerugian fiskal, penghindaran pajak 


\section{PENDAHULUAN}

Penghindaran pajak (tax avoidance) telah menjadi perhatian utama hampir di seluruh negara, terutama atas transaksi bisnis lintas negara yang dilakukan oleh perusahaan yang memiliki hubungan istimewa. Industri perbankan Indonesia juga tidak terlepas dari isu penghindaran pajak dimana potensi penghidaran pajak dalam industri perbankan dalam menjalankan fungsi intermediary dapat terjadi dalam konteks: (i) bank sebagai pelaku penghindaran pajak dengan berbagai skema; dan (ii) bank sebagai channel yang digunakan oleh pihak ketiga untuk melakukan praktik penghindaran pajak (Darussalam, 2010).

Hasil investigasi dan kajian dari tim Perkumpulan Prakarsa menemukan potensi kerugian negara dari penerimaan pajak yang bersumber dari sektor perbankan dan lembaga keuangan lainnya setiap tahun lebih kurang sebesar Rp 10 Triliun hingga Rp 12 Triliun (Kusuma, 2014). Salah satu industri perbankan yang diketahui melakukan praktek tax avoidance di Indonesia adalah PT Bank Central Asia Tbk dimana Dirjen Pajak mengoreksi laba BCA pada 1999, bukan hanya Rp 174 Miliar, tetapi Rp 6,78 Triliun. Salah satu yang mendongkrak angka laba tersebut yaitu penghapusan utang bermasalah Rp 5,77 Triliun yang dianggap sebagai pemasukan bagi BCA. Oleh karena itu, BCA harus membayar pajak Rp 375 miliar (Kusuma, 2014).

Fenomena penghindaran pajak oleh perusahaan-perusahaan di Indonesia cukup besar jumlahnya. Berdasarkan data pajak yang di sampaikan oleh Dirjen Pajak pada tahun 2012 ada 4.000 perusahaan PMA yang melaporkan nihil nilai pajaknya, perusahaan tersebut diketahui ada yang mengalami kerugian selama 7 tahun berturut-turut (DJP, 2013). Sedangkan di Amerika paling tidak terdapat seperempat dari jumlah perusahaan telah melakukan penghindaran pajak yakni dengan membayar pajak kurang dari 20\% padahal rata-rata pajak yang dibayarkan perusahaan mendekati 30\% (Dyreng et al., 2008).

Terdapat beberapa faktor yang berpengaruh terhadap upaya penghindaran pajak yang dapat diidentifikasi dari beberapa penelitian terdahulu, yaitu profitabilitas, kepemilikan keluarga, dewan komisaris independen, komite audit, ukuran perusahaan, leverage dan kompensasi rugi fiskal (Richardson \& Lanis, 2007; Annisa \& Kurniasih, 2012; Prakosa, 2014).

Profitabilitas suatu perusahaan menggambarkan kemampuan suatu perusahaan dalam menghasilkan laba selama periode tertentu pada tingkat penjualan, aset, dan modal saham tertentu. Salah satu rasio profitabilitas adalah Return on Assets (ROA), dimana ROA memiliki keterkaitan dengan laba bersih perusahaan dan pengenaan pajak penghasilan untuk perusahaan. Semakin tinggi profitabilitas perusahaan akan semakin tinggi pula laba bersih perusahaan yang dihasilkan, dimana peningkatan laba mengakibatkan jumlah pajak yang harus dibayar juga semakin tinggi. Sehingga, semakin tinggi profitabilitas perusahaan, maka perencanaan pajak yang dilakukan juga semakin matang, sehingga menghasilkan nilai pajak yang optimal yang seringkali diikuti dengan kecenderungan peningkatan aktivitas penghindaran pajak.

Leverage menunjukkan pembiayaan suatu perusahaan dari utang yang mencerminkan semakin tingginya nilai perusahaan. Leverage juga merupakan penambahan jumlah utang yang mengakibatkan timbulnya pos biaya tambahan berupa bunga atau interest dan pengurangan beban pajak penghasilan WP Badan. Richardson dan Lanis (2007) meneliti pengaruh leverage dan size terhadap penghindaran pajak dan menyatakan bahwa semakin tinggi nilai utang perusahaan (leverage) maka nilai effective tax rates (ETRs) perusahaan akan semakin rendah hal tersebut disebabkan adanya beban bunga yang mengurangi beban pajak. Artinya leverage berpengaruh negatif terhadap penghindaran 
pajak. Richardson dan Lanis (2007) menyatakan semakin besar perusahaan maka akan semakin rendah ETRs yang dimilikinya, hal ini dikarenakan perusahaan besar lebih mampu menggunakan sumber daya yang dimilikinya untuk membuat suatu perencanaan pajak yang baik.

Desai dan Dhamapala (2006) menjelaskan bahwa mekanisme tax avoidance harus meningkatkan nilai pemegang saham dan sebuah perspektif agency menyatakan bahwa tax avoidance menyediakan prediksi yang berbeda. Secara spesifik corporate governance menjadi determinan yang penting dari penilaian yang dimaksud untuk penghematan pajak. Sartori (2008), terkait pengaruh strategi perpajakan terhadap corporate governance menjelaskan apabila suatu perusahaan memiliki suatu mekanisme corporate governance yang terstruktur dengan baik maka akan berbanding lurus dengan kepatuhan perusahaan dalam memenuhi kewajiban perpajakannya.

Isu corporate governance mulai berkembang pada tahun 1998, ketika di Indonesia mengalami krisis moneter berkepanjangan. Tata kelola perusahaan merupakan sistem dan struktur yang mengatur hubungan antara pihak manajemen dengan pemilik baik yang memiliki saham mayoritas maupun minoritas di suatu perusahaan yang berguna untuk melindungi investor dari adanya perbedaan kepentingan pemegang saham (principle) dengan pihak manajemen (agent) (Farooque et al., 2014; Suyono, 2016; Suyono \& Farooque, 2018). Dalam penelitian ini tata kelola perusahaan diukur dengan dua proksi, yakni proksi komposisi komisaris independen dan proksi jumlah komite audit. Dewan komisaris dalam menjalankan fungsi pengawasan dapat mempengaruhi pihak manajemen untuk menyusun laporan keuangan yang berkualitas (Suyono, 2016; Suyono \& Farooque, 2018). Komisaris Independen dapat melaksanakan fungsi monitoring untuk mendukung pengelolaan perusahaan yang baik dan menjadikan laporan keuangan lebih objektif
(Suyono, 2016; Suyono \& Farooque, 2018). Komite audit bertugas melakukan kontrol dan pengawasan terhadap proses penyusunan laporan keuangan perusahaan untuk menghindari kecurangan yang dilakukan oleh pihak manajemen.

Faktor selanjutnya yang dapat mempengaruhi tindakan penghindaran pajak pada perusahaan perbankan konvensional yaitu kompensasi rugi fiskal. Kompensasi rugi fiskal merupakan proses peralihan kerugian dari satu periode ke periode lainnya untuk menunjukkan bahwa perusahaan yang sedang merugi tidak akan dibebani pajak sesuai dengan aturan dalam Pajak Penghasilan diatur pada Pasal 6 ayat (2) Undang-Undang No.17 tahun 2000 tentang pajak pe ghasilan.

Ukuran perusahaan merupakan salah satu faktor yang menunjukkan kestabilan dan kemampuan perusahaan untuk melakukan aktivitas ekonominya. Semakin besar ukuran suatu perusahaan maka semakin menjadi pusat perhatian pemerintah dan akan menimbulkan kecenderungan bagi para manajer perusahaan untuk berlaku patuh (compliances) atau agresif (tax avoidance) dalam perpajakan. Perusahaan beraktiva besar lebih stabil dan lebih mampu dalam menghasilkan laba dibanding perusahaan dengan total aktiva yang kecil (Rachmawati dan Triatmoko, 2007). Watt dan Zimmerman (1986) menyatakan bahwa manajer perusahaan besar cenderung melakukan pemilihan metode akuntansi yang menangguhkan laba yang dilaporkan dari periode sekarang ke periode mendatang guna memperkecil laba yang dilaporkan, namun perusahaan tidak selalu dapat menggunakan power yang dimilikinya untuk melakukan perencanaan pajak karena adanya batasan berupa kemungkinan menjadi sorotan dan sasaran dari keputusan regulator.

Berbeda dengan penelitian sebelumnya, pada penelitian ini menambahkan faktor leverage sebagai faktor yang berpengaruh terhadap penghindaran pajak. Penelitian ini mencoba meneliti faktor-faktor 
yang diduga berpengaruh terhadap penghindaran pajak, yaitu dari faktor profitabilitas, leverage, tata kelola perusahaan, dan kompensasi rugi fiskal. Serta pada penelitian ini penghindaran pajak diproksikan dengan book tax difference atau disebut pula book tax gap. Penggunaan metode book tax difference ini diharapkan mampu mengidentifikasi aktivitas perencanaan pajak dan manajemen laba perusahaan berdasarkan penghasilan kena pajak dan laba bersih serta perbandingan dengan aset rata-rata. Berdasarkan latar belakang masalah di atas, maka dapat diajukan pertanyaan penelitian apakah profitabilitas, leverage, komposisi komisaris independen, komite audit, kompensasi rugi fiskal berpengaruh terhadap penghindaran pajak?

Teori Regulasi, pada dasarnya membuka persamaan ekonomi dengan memasukkan proses politik dan dilema etis dalam masyarakat. Jelas sekali, persoalan ekonomi bukanlah sebuah transaksi untung rugi, efektifitas dan efisiensi belaka, tetapi menyangkut dimensi keadilan, konfigurasi pembagian kekuasaan dsb. Untuk itu, tidak ada satu solusi terbaik seperti versineo-klasik, yang mengaggap pasar sebagai satu-satunya solusi yang paling baik dari segala masalah ekonomi (one best way solution) (Pratama, 2006).

Teori Regulasi, bukan dalam pengertian regulation (bahasa Inggris) yang berarti "aturan" (regulasi dalam bahasa Indonesia), melainkan régulation yang berarti bahwa ekonomi harus dibangun dalam sebuah konteks relasi sosial tertentu. Dalam hal ini, Teori Regulasi memiliki pendekatan heterodox (lawan dari orthodox). Ekonomi bukan semata menyangkut pilihan rasional (rational choice), prinsip maksimalisasi (pareto optimum), biaya transaksi (transaction cost), melainkan juga menyangkut kebiasaan-kebiasaan yang sudah mengakar dalam masyarakat (habitus). Model ekonomi makro yang digunakan adalah Model Kalechian (neo-cambregian) yang sarat dengan campur tangan negara dalam ekonomi (Pratama, 2006).

Terkait dengan pembayaran pajak oleh wajib pajak, pemerintah mengharapkan individu secara sadar dan berkeinginan atas kehendaknya sendiri untuk membayar pajak, patuh terhadap pajak. Namun pada prakteknya, seseorang akan berusaha melakukan penghindaran pajak, manakala yang bersangkutan berdasarkan hitung-hitungan yang telah dilakukannya berpendapat bahwa nilai pajak yang disembunyikan jauh lebih menguntungkan dibandingkan dengan resiko apabila dia tertangkap tangan dan dikenakan sanksi sekalipun (maximize expected utility) (Widihartanto, 2011).

Berdasarkan logika berpikir itu pula kemudian otoritas pajak menterjemahkannya ke dalam berbagai kebijakan sebagai upaya meminimalisir praktek penghindaran pajak dengan, pertama, memperbesar peluang terdeteksi bagi mereka yang melakukan penghindaran pajak melalui, antara lain audit, pemungutan pajak melalui pihak ketiga (withholding tax), dan pelaporan oleh pihak ketiga (third party reporting). Kedua, dengan cara meningkatkan sanksi yang akan dikenakan terhadap mereka yang terdeteksi melakukan penghindaran pajak. Namun kebijakan ini tidak sepenuhnya membuat seseorang membayar pajak (Widihartanto, 2011).

Salah satu tujuan perusahaan melakukan perencanaan pajak (tax planning) yaitu untuk meminimalisasi pajak yang harus dibayarkan. Akan tetapi tidak selalu kegiatan tax planning yang dilakukan perusahaan membawa dampak baik bagi perusahaan itu sendiri. Kegiatan tax planning yang tidak terkontrol dengan baik dapat memunculkan risiko bagi perusahaan antara lain denda dan buruknya reputasi perusahaan dimata publik. Apabila penghindaran pajak (tax avoidance) melebihi batas atau melanggar hukum dan ketentuan yang berlaku maka aktivitas tersebut dapat tergolong ke dalam penggelapan pajak (tax evasion). Penggelapan pajak adalah usaha 
untuk mengurangi utang pajak yang bersifat ilegal. Oleh karena itu persoalan penghindaran pajak merupakan persoalan yang rumit dan unik. Di satu sisi penghindaran pajak diperbolehkan, tapi di sisi yang lain penghindaran pajak tidak diinginkan (Budiman \& Setiyono, 2012). Penghindaran pajak dilakukan dengan menggunakan strategi, seperti memanfaatkan pengecualian dan potongan yang diperkenankan dalam ketentuan, maupun memanfaatkan hal-hal yang belum diatur (loopholes) dalam peraturan perpajakan yang berlaku.

Pengukuran penghindaran pajak sulit dilakukan, hal ini disebabkan data pembayaran pajak dalam Surat Pemberitahuan Pajak (SPT$\mathrm{PPh}$ ) bersifat rahasia. Untuk mengukur estimasi penghindaran pajak, pada penelitian ini digunakan metode Book Tax Difference (BTD). Book-tax difference bisa timbul karena adanya aktivitas perencanaan pajak dan manajemen laba di dalam perusahaan, maka nilai residu dari regresi nilai book-tax difference dan nilai total akrual diharapkan murni cerminan dari aktivitas perencanaan pajak (Desai \& Dharmapala, 2006). Walaupun tidak semua tindakan yang dilakukan perusahaan melanggar peraturan, akan tetapi semakin banyak celah yang digunakan perusahaan, semakin dianggap agresif dalam melakukan penghindaran pajak.

Menurut Prakosa (2014), ada tiga tahapan atau langkah akan dilakukan perusahaan dalam meminimalkan pajak yang dikenakan. Langkah pertama, perusahaan berusaha untuk menghindari pajak baik secara legal maupun ilegal. Langkah kedua, mengurangi beban pajak seminimal mungkin baik secara legal maupun ilegal. Langkah ketiga, apabila kedua langkah sebelumnya tidak dapat dilakukan maka wajib pajak akan membayar pajak tersebut.

Dari perspektif teori akuntansi positif (PAT) yang dikembangkan oleh Watts dan Zimmerman (1986) maka political Cost berhubungan dengan ukuran perusahaan dimana semakin besar ukuran perusahaan profitabilitas yang tinggi akan meningkatkan juga biaya politisnya. Perusahaan yang besar menghasilkan laba yang besar akibatnya akan membayar pajak dan biaya politik lainnya yang besar pula. Manajer mempunyai kecenderungan untuk mengecilkan laba yang dilaporkan untuk mengurangi biaya politis yang potensial. Biaya politik tidak hanya berkaitan dengan pajak, juga tuntutan buruh, biaya kasus persidangan dan lainnya. Penerapan prinsip akuntansi yang konservatif karena biaya politis akan memberi dampak pada pelaporan laba perusahaan yang kecil.

\section{Profitabilitas dan Penghindaran Pajak}

Profitabilitas merupakan gambaran kinerja keuangan perusahaan dalam menghasilkan laba dari pengelolaan aset yang dikenal dengan Return On Asset (ROA) (Prakosa, 2014). Profitabilitas perusahaan yang semakin tinggi dapat menyebabkan perusahaan melakukan perencanaan pajak yang matang sehingga menghasilkan pajak yang optimal, dengan memanfaatkan celah penghindaran pajak. Perusahaan yang mampu menghasilkan keuntungan yang besar, cenderung menginginkan pajak yang dibayarkan tidak terlalu besar.

Hubungan profitabilitas dengan teori agensi, teori regulasi dan PAT dalam penghindaran pajak adalah bahwa pajak merupakan kontribusi wajib bagi perorangan atau badan (perusahaan) yang disetorkan kepada negara. Namun demikian, para pemilik modal (principal) memiliki sifat enggan untuk mengorbankan sebagian laba yang diperoleh dari hasil operasi perusahaan. Di sisi lain para pemilik saham perusahaan juga tidak bisa mengelak sepenuhnya dari kewajiban mereka untuk membayar pajak tetapi hanya dapat mengurangi jumlah pajak yang disetorkan tanpa ada implikasi terjadinya restitusi pajak atau kurang bayar pajak. Karena itu pihak agen (manajemen perusahaan) melakukan usahausaha untuk meminimalkan pembayaran pajak 
dan perilaku penghindaran pajak dengan cara membuat perencanaan pajak (tax planning).

Penelitian Kurniasih dan Sari (2013) menemukan bahwa profitabiltas perusahaan yang diukur dengan ROA, berpengaruh signifikan terhadap penghindaran pajak perusahaan manufaktur periode 2007-2010. Kurniasih menyatakan hasil yang signifikan dipengaruhi oleh tingkat profitabilitas perusahaan yang cenderung stabil dan cukup baik. Selain itu hasil penelitian dari Rinaldi dan Cheisviyanny (2015) juga membuktikan bahwa variabel profitabilitas berpengaruh positif signifikan terhadap tax avoidance, yang dapat dimaknai bahwa semakin tinggi profitabilitas yang diperoleh suatu perusahaan maka semakin besar penghindaran pajak yang dilakukan perusahaan tersebut. Dari teori dan hasil penelitian terdahulu yang telah diuraikan di atas, dapat dirumuskan hipotesis penelitian sebagai berikut:

$\mathrm{H}_{1}$ : Profitabilitas berpengaruh positif terhadap penghindaran pajak.

\section{Leverage dan Penghindaran Pajak}

Leverage merupakan rasio yang mengukur seberapa jauh perusahaan menggunakan utang dalam pembiayaan. Leverage juga menggambarkan hubungan antara total assets dengan modal saham biasa atau menunjukkan penggunaan utang untuk meningkatkan laba. Perusahaan dimungkinkan menggunakan utang untuk memenuhi kebutuhan operasional dan investasi perusahaan. Akan tetapi, utang akan menimbulkan beban tetap (fixed rate of return) yang disebut dengan bunga. Semakin besar utang maka laba kena pajak menjadi lebih kecil karena insentif pajak atas bunga utang semakin besar. Hal tersebut membawa implikasi meningkatnya penggunaan utang oleh perusahaan.

Bunga atas pinjaman merupakan salah satu pemanfaatan deductible expense yang diatur dalam Pasal 6 UndangUndang No. 36 Tahun 2008. Biaya bunga yang semakin tinggi akan menyebabkan tingginya beban perusahan yang akhirnya berkurangnya pajak yang dibayarkan perusahaan. Dengan demikian perusahaan akan membayar pajaknya dalam jumlah kecil.

Teori agensi menyatakan hubungan kontrak antara agen (manajemen suatu usaha) dan prinsipal (pemilik usaha), di mana agen melakukan tugas-tugas tertentu untuk prinsipal yang pada prinsipnya adalah memberi keuntungan yang sebesar-besarnya kepada prinsipal, sehingga agen berupaya maksimal untuk memenuhi tugasnya tersebut. Salah satu tugas agen atau pihak manajemen adalah membuat laporan keuangan, termasuk di dalamnya laporan tentang leverage perusahaan terkait penghindaran pajak. Pihak agen dapat melaporkan keadaan leverage perusahaan yang dapat menghindarkan perusahaannya dari membayar pajak selama periode waktu tertentu sehingga laba perusahaan tidak berkurang karena harus membayar pajak, hal ini adalah untuk kepentingan principal.

Penelitian Ozkan (2001) memberikan bukti bahwa perusahaan yang memiliki kewajiban pajak tinggi akan memilih berutang untuk mengurangi pajak, sehingga tindakan berhutang secara disengaja ini masuk dalam kategori tindakan agresif terhadap pajak. Biaya bunga yang semakin tinggi akan memberikan pengaruh berkurangnya beban pajak perusahaan sehing semakin tinggi nilai utang perusahaan maka nilai CETR (Cash Effective Tax Rates) perusahaan akan semakin rendah (Richardson \& Lanis, 2007). Hal ini sejalan dengan penelitian yang dilakukan oleh Swingly dan Sukartha (2015) yang menemukan bahwa semakin tinggi leverage maka semakin rendah tax avoidance yang dilakukan perusahaan karena timbulnya biaya bunga. Hasil penelitian Richardson dan Lanis (2007) juga menyatakan bahwa leverage berpengaruh negatif terhadap penghindaran pajak. Berdasarkan berbagai argument dan hasil penelitian terdahulu di atas, maka hipotesis kedua dirumuskan sebagai berikut: 
$\mathrm{H}_{2}$ : Leverage berpengaruh negatif terhadap penghindaran pajak.

\section{Komisaris Independen dan Penghindaran Pajak}

Corporate governance secara definitif merupakan sistem yang mengatur dan mengendalikan perusahaan untuk menciptakan nilai tambah (value added) untuk semua stockholder (Desai dan Dharmapala, 2007). Tata kelola perusahaan didefinisikan sebagai efektivitas mekanisme yang bertujuan meminimumkan konflik keagenan, dengan penekanan khusus pada mekanisme legal yang mencegah dilakukannya ekspropriasi atas pemegang saham minoritas (Farooque et al., 2014; Suyono, 2016). Dewan komisaris sebagai salah satu instrument corporate governance dalam menjalankan fungsi pengawasan dapat mempengaruhi pihak manajemen untuk menyusun laporan keuangan yang berkualitas (Suyono, 2016). Komisaris Independen dapat melaksanakan fungsi monitoring untuk mendukung pengelolaan perusahaan yang baik dan menjadikan laporan keuangan lebih objektif (Suyono, 2016).

Komisaris independen dapat melaksanakan fungsi monitoring untuk mendukung pengelolaan perusahaan yang baik dan menjadikan laporan keuangan lebih objektif (Prakosa, 2014). Salah satu fungsi monitoring oleh dewan komisaris independen ini adalah dengan cara melakukan pengawasan dan kontrol terhadap kebijakan-kebijakan direksi yang dianggap dapat merugikan perusahaan maupun citra perusahaan di masa depan dimana salah satunya adalah praktik penghindaran pajak.

Hasil penelitian Maharani dan Suardana (2014) dan Prakosa (2014) menunjukkan bahwa dewan komisaris independen berpengaruh negatif terhadap tax avoidance. Semakin besar proporsi dewan komisaris independen akan menghambat perusahaan untuk melakukan penghindaran pajak. Sehingga berdasar argument dan hasil penelitian terahulu di atas, maka hipotesis ketiga dirumuskan sebagai berikut:

$\mathrm{H}_{3}$ : Komposisi Komisaris independen berpengaruh negatif terhadap penghindaran pajak.

\section{Komite Audit dan Penghindaran Pajak}

Komite audit bertugas melakukan kontrol dan pengawasan terhadap proses penyusunan laporan keuangan perusahaan untuk menghindari kecurangan yang dilakukan oleh pihak manajemen. Komite audit berfungsi memberikan pandangan mengenai masalahmasalah yang berhubungan dengan kebijakan keuangan, akuntansi dan pengendalian internal perusahaan (Suyono, 2016). Berdasarkan teori agensi, komite audit adalah agen yang dibentuk oleh dewan komisaris yang bertugas untuk melakukan kontrol dan pengawasan terhadap proses penyusunan laporan keuangan perusahaan untuk menghindari kecurangan yang dilakukan oleh pihak manajemen. Berjalannya fungsi komite audit secara efektif memungkinkan pengendalian pada perusahaan dan laporan keuangan yang lebih baik serta mendukung corporate governance (Prakosa, 2014). Dengan demikian maka pihak principal sebagai investor atau pemilik perusahaan dapat memperoleh informasi keuangan yang sebenarnya sesuai keadaan perusahaan dari pihak agen yaitu manajemen perusahaan, sehingga tidak terjadi asimetri informasi sehingga pihak principal dapat mengambil kebijakan dengan tepat. Semakin besar proporsi komite audit, maka semakin menghambat perusahaan untuk melakukan penghindaran pajak. Maharani dan Suardana (2014) dan Annisa dan Kurniasih (2012) menguji pengaruh komite audit terhadap tax avoidance. Hasilnya menunjukkan bahwa komite audit berpengaruh signifikan terhadap tax avoidance. Berdasar argument dan temuan hasil penelitian terdahulu yang telah diuraikan di atas maka hipotesis keempat dirumuskan sebagai berikut: $\mathrm{H}_{4}$ : Jumlah komite audit berpengaruh negatif terhadap penghindaran pajak. 


\section{Kompensasi Rugi Fiskal dan Penghindaran Pajak}

Proses membawa kerugian dalam satu tahun pajak ke tahun-tahun pajak berikutnya dinamakan dengan kompensasi kerugian. Kurniasih dan Sari (2013) mengatakan kompensasi rugi fiskal berpengaruh negatif terhadap tax avoidance, karena kerugian tersebut dapat mengurangi beban pajak pada tahun berikutnya. Perusahaan yang telah merugi dalam satu periode akuntansi diberikan keringanan untuk membayar pajaknya (Prakosa, 2014).

Sesuai dengan Undang-Undang No.36 tahun 2008 tentang Pajak Penghasilan, mulai tahun 2009 kerugian tersebut dapat dikompensasikan selama lima tahun ke depan dan laba perusahaan akan digunakan untuk mengurangi jumlah kompensasi kerugian tersebut sedangkan untuk tahun pajak sebelumnya berlaku ketentuan Undang-Undang No. 17 tahun 2000 tentang Pajak Penghasilan. Akibatnya, selama lima tahun tersebut, perusahaan akan terhindar dari beban pajak, karena laba kena pajak akan digunakan untuk mengurangi jumlah kompensasi kerugian perusahaan (Prakosa, 2014). Hal ini membuat perusahaan yang mengalami kerugian fiskal biasanya tidak termotivasi untuk melakukan penghindaran pajak karena adanya kompensasi rugi fiskal yang didapatkan oleh perusahaan sehingga semakin besar kompensasi kerugian fiskal maka semakin kecil tindakan penghindaran pajak perusahaan tersebut.

Dalam teori agensi dijelaskan bahwa principal mendelegasikan beberapa wewenang kepada agent yang salah satunya adalah pengambilan keputusan strategis perusahaan selain dari hanya mengelola sumberdaya yang dimiliki principal. Salah satunya adalah dengan membuat laporan keuangan yang menggambarkan kondisi perusahaan sedang mengalami kerugian secara fiskal, sehingga perusahaan terhindar dari beban pajak dan laba yang diperoleh perusahaan tidak dikurangi oleh pajak. Pada dasarnya para pemilik saham menginginkan efisiensi biaya pada semua pos biaya termasuk biaya pajak yang harus dikeluarkan perusahaan berdasarkan jumlah laba yang didapat perusahaan, sehingga agent berusaha untuk melakukan hal itu salah satunya dengan cara membuat laporan rugi fiskal. Hasil penelitian Kurniasih dan Sari (2013) menunjukkan bahwa kompensasi rugi fiskal berpengaruh negatif terhadap tax avoidance. Dari teori dan penelitian terdahulu yang telah diuraikan di atas dapat dirumuskan hipotesis kelima sebagai berikut:

$\mathrm{H}_{5}$ : Kompensasi rugi fiskal berpengaruh negatif terhadap penghindaran pajak

\section{METODE PENELITIAN}

Populasi yang digunakan dalam penelitian ini adalah seluruh perusahaan perbankan konvensional yang terdaftar di Bursa Efek Indonesia tahun 2011 sampai dengan tahun 2015, yang berjumlah 41 perusahaan. Pengambilan sampel perusahaan dalam penelitian ini menggunakan teknik purposive sampling dengan criteria sebagai berikut: 
Tabel 1 Kriteria Pemilihan Sampel

\begin{tabular}{clc}
\hline No & \multicolumn{1}{c}{ Kriteria } & \\
\hline 1 & $\begin{array}{l}\text { Perusahaan perbankan yang tercatat di Bursa Efek Indonesia (BEI) } \\
\text { periode 2011-2015 }\end{array}$ & 41 \\
2 & $\begin{array}{l}\text { Perusahaan yang tidak menerbitkan laporan keuangan secara } \\
\text { berturut-turut selama periode penelitian }\end{array}$ & \\
$3 \quad \begin{array}{l}\text { Perusahaan yang tidak mempunyai kelengkapan data yang } \\
\text { dibutuhkan dalam penelitian secara berturut-turut selama periode }\end{array}$ & - \\
$\quad \begin{array}{l}\text { penelitian } \\
\text { Jumlah perusahaan yang dijadikan sampel }\end{array}$ & 30 \\
Jumlah observasi selama lima tahun (2011-2015) & 150 \\
\hline
\end{tabular}

Sebagai variable dependen dalam penelitian ini adalah penghindaran pajak yang dalam penelitian ini pengukurannya menggunakan model Book-tax difference (BTD) yang diharapkan mampu mengidentifikasi aktivitas perencanaan pajak dan manajemen laba di dalam suatu perusahaan (Desai \& Dharmapala, 2006; Liao \& Fu, 2015) dengan rumus sebagai berikut:

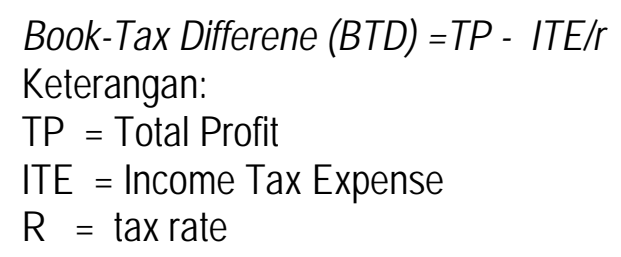

Profitabilitas dalam penelitian ini diproksi dengan Return on Asset (ROA). Leverage dalam penelitian ini diproksi dengan Debt to Equity Ratio (DER). Komposisi komisaris independen diukur menggunakan persentase jumlah komisaris independen terhadap jumlah total komisaris dalam susunan dewan komisaris perusahaan sampel tahun amatan. Variabel komite audit diukur dengan jumlah total anggota komite audit. Kompensasi rugi fiskal, dapat diukur dengan menggunakan variabel dummy, yang akan diberikan nilai 1 jika terdapat kompensasi rugi fiskal pada awal tahun $t$ dan nilai 0 jika tidak terdapat kompensasi rugi fiskal (Sari dan Martani, 2010). Ukuran perusahaan (Size) sebagai variable control diukur dengan menggunakan natural logarithm total assets. Selanjutnya, persamaan regresi dalam penelitian ini disajikan sebagai berikut:

$P P=\alpha+\beta_{1} P-\beta_{2} L-\beta_{3} K I-\beta_{4} K A-\beta_{5} K R F-$

$\beta_{5} U P+\varepsilon$

Dimana:

$$
\begin{array}{ll}
a & =\text { Konstanta } \\
\beta_{1}-\beta_{6} & =\text { Koefisien regresi } \\
\mathrm{PP} & =\text { Penghindaran Pajak } \\
\mathrm{P} & =\text { Profitabilitas } \\
\mathrm{L} & =\text { Leverage } \\
\mathrm{KI} & =\text { Komposisi Komisaris Independen } \\
\mathrm{KA} & =\text { Jumlah Komite Audit } \\
\mathrm{KRF} & =\text { Kompensasi Rugi Fiskal } \\
\mathrm{UP} & =\text { Ukuran Perusahaan } \\
\mathrm{e} & =\text { Error / variabel pengganggu }
\end{array}
$$

\section{HASIL DAN DISKUSI}

Hasil analisis statistic diskriptir dalam penelitian ini disajikan dalam table 2 berikut ini: 
Tabel 2 Statistik Diskriptif Variabel Penelitian

\begin{tabular}{lrrrl}
\hline \multicolumn{1}{c}{ Variabel } & Min & Max & Mean & $\begin{array}{l}\text { Std. } \\
\text { Dev }\end{array}$ \\
\hline Profitabilitas (P) & $-0,078$ & 1,293 & 0,040 & 0,162 \\
Leverage (L) & 1,000 & 15,620 & 7,820 & 2,492 \\
Komisaris Independen (KI) & 0,033 & 0,666 & 0,366 & 0,134 \\
Komite Audit (KA) & 3,000 & 8,000 & 3,930 & 1,124 \\
Kompensasi Rugi Fiskal (KRF) & 0,000 & 1,000 & 0,070 & 0,250 \\
Ukuran Perusahaan (UP) & 27,474 & 34,444 & 31,213 & 1,699 \\
Ln Penghindaran Pajak (PP) & $-8,520$ & $-0,840$ & $-5,510$ & 1,070 \\
\hline
\end{tabular}

Sumber: Output SPSS untuk statistk diskriptif

Tabel 2 di atas menyajikan statistik deskriptif dari variabel-variabel yang ada di dalam penelitian ini. Hasilnya menunjukkan relatif kecilnya rata-rata profitabilitas perusahaan sampel (4\%) dan tingginya leverage dengan rata-rata $782 \%$. Selanjutnya table 2 juga menunjukkan rata-rata proporsi komisaris independen sebesar 37\%, rata-rata jumlah komite audit 4 orang. Lebih lanjut data menunjukkan rata-rata natural logaritma untuk ukuran perusahaan dan penghindaran pajak adalah 31,213 dan -5,510. Rangkuman hasil analsis regresi dalam penelitian ini disajikan dalam table 3 berikut ini:

Tabel 3 Rangkuman Hasil Analsis Regresi

\begin{tabular}{|c|c|c|c|}
\hline Koefisien & Beta & $t$ & Sig. \\
\hline (Constant) & $-6,773$ & $-5,230$ & 0,000 \\
\hline Profitabilitas (P) & 4,718 & 11,599 & 0,000 \\
\hline Leverage $(\mathrm{L})$ & $-0,080$ & $-3,148$ & 0,002 \\
\hline Komisaris independen (KI) & 0,427 & 0,906 & 0,367 \\
\hline Komite Audit (KA) & $-0,027$ & $-0,427$ & 0,670 \\
\hline Kompensasi Rugi Fiskal (KRF) & $-0,710$ & $-2,738$ & 0,007 \\
\hline Ukuran Perusahaan (UP) & 0,052 & 1,177 & 0,242 \\
\hline \multicolumn{4}{|l|}{ a. Dependent Variable: PP } \\
\hline$F=3,233 \quad$ Sig. 0,000 & \multirow{2}{*}{\multicolumn{3}{|c|}{ Adiusted R Sauare $=0.604$}} \\
\hline R Square $=0,624$ & & & \\
\hline
\end{tabular}

Tabel 3 di atas menunjukkan bahwa profitabilitas berpengaruh positif terhadap penghindaran pajak dengan signifikansi sebesar 0,000; leverage dan kompensasi rugi fiskal berpengaruh negatif terhadap penghindaran pajak dengan signifikansi masing-masing sebesar 0,002 dan 0,007. Adapun komisaris independen, komite audit dan ukuran perusahaan tidak berpengaruh signifikan terhadap penghindaran pajak dengan nilai signifikansi lebih besar dari $a=0,05$.
Hipotesis pertama dalam penelitian ini menyatakan bahwa.profitabilitas berpengaruh positif terhadap penghindaran pajak. Hasil analisis regresi dalam penelitian ini menemukan bahwa profitabilitas berpengaruh positif terhadap penghindaran pajak sehingga hipotesis pertama didukung. Hal ini berarti bahwa profitabilitas merupakan faktor penentu terhadap tinggi rendahnya penghindaran pajak. Pengaruh yang positif, mengandung arti bahwa semakin tinggi profitabilitas suatu perusahaan 
perbankan maka akan semakin tinggi pula penghindaran pajak yang dilakukan di perusahaan perbankan tersebut. ROA berkaitan dengan laba bersih perusahaan dan pengenaan pajak penghasilan untuk Wajib Pajak Badan. Semakin tinggi ROA, semakin tinggi keuntungan perusahaan sehingga semakin baik pengelolaan aktiva perusahaan, seperti pendapat yang disampaikan oleh Lestari dan Sugiharto (2007), ROA merupakan pengukur keuntungan bersih yang diperoleh dari penggunaan aktiva. Semakin tinggi rasio ini maka semakin baik produktivitas aset dalam memperoleh keuntungan bersih.

Hubungan profitabilitas dengan teori agensi, teori regulasi dan PAT dalam penghindaran pajak adalah bahwa pajak merupakan kontribusi wajib bagi perorangan atau badan (perusahaan) yang disetorkan kepada negara. Hasil penelitian ini dapat menggambarkan bahwa para pemilik modal (principal) tidak ingin mengorbankan sebagian laba yang diperoleh dari hasil operasi perusahaannya diberikan kepada negara dalam bentuk pembayaran pajak sesuai kewajibannya, sehingga melakukan upaya dengan mengurangi jumlah pajak yang disetorkan tanpa ada implikasi terjadinya restitusi pajak atau kurang bayar pajak. Oleh karena itu, pihak agen (manajemen perusahaan) melakukan usahausaha untuk meminimalkan pembayaran pajak dan perilaku penghindaran pajak dengan cara membuat perencanaan pajak (tax planning).

Temuan dalam penelitian ini mendukung argument Chen et al. (2010) yang menyatakan bahwa perusahaan yang memiliki profitabilitas tinggi memiliki kesempatan untuk memposisikan diri dalam tax planning untuk mengurangi jumlah beban kewajiban perpajakan. Hal ini juga ditunjukkan pada data hasil penelitian ini, di mana perusahaan yang memiliki profitabilitas yaitu ROA yang tinggi memiliki rasio penghindaran pajak yang besar, dan sebaliknya perusahaan yang memiliki ROA rendah memiliki rasio penghindaran pajak yang kecil. Ini berarti bahwa semakin tinggi profitabilitas maka semakin tinggi juga penghindaran pajak, dan semakin rendah profitabilitas maka semakin rendah pula penghindaran pajak yang dilakukan suatu perusahaan.

Penelitian ini sejalan dengan Kurniasih dan Sari (2013) dan Prakoso (2014) yang menunjukkan bahwa ROA berpengaruh positif terhadap tax avoidance. Lebih lanjut, penelitian ini didukung oleh hasil penelitian Rinaldi dan Cheisviyanny (2015) yang membuktikan bahwa variabel profitabilitas berpengaruh positif signifikan terhadap tax avoidance, yang dapat dimaknai bahwa semakin tinggi profitabilitas yang diperoleh suatu perusahaan maka semakin besar kemungkinan upaya penghindaran pajak yang dilakukan perusahaan tersebut.

Hipotesis kedua dalam penelitian ini menyatakan bahwa leverage berpengaruh negatif terhadap penghindaran pajak. Hasil analisis regresi dalam penelitian ini menemukan bahwa leverage berpengaruh negative terhadap penghindaran pajak, sehingga hipotesis kedua dalam penelitian ini didukung. Hal ini berarti bahwa temuan dalam penelitian ini mendukung argument yang menyatakan bahwa tingginya nilai hutang yang dimiliki perusahaan akan menyebabkan perusahaan harus membayar beban bunga yang tinggi yang pada akhirnya akan mengurangi kewajiban pajak pada tahun yang bersangkutan. Hasil ini menunjukkan bahwa leverage merupakan faktor yang dapat menentukan tinggi rendahnya penghindaran pajak suatu perusahaan perbankan. Pengaruh yang negatif, mengandung arti bahwa semakin tinggi leverage suatu perusahaan perbankan maka akan semakin rendah nilai penghindaran pajak yang dilakukan perusahaan tersebut. Hal ini karena jumlah pajak yang terutang terkurangi dengan semakin tingginya kewajiban bunga yang harus dibayar yang juga mengakibatkan turunnya laba perusahaan. Dengan demikian ketika laba perusahaan turun akibat tingginya beban bunga yang harus dibayar maka peluang 
perusahaan melakukan upaya-upaya penghindaran pajak juga akan menurun.

Leverage merupakan rasio yang mengukur seberapa jauh perusahaan menggunakan utang, menggambarkan hubungan antara total assets dengan modal saham biasa atau menunjukkan penggunaan utang untuk meningkatkan laba. Utang yang mengakibatkan munculnya beban bunga dapat menjadi pengurang laba kena pajak, sedangkan deviden yang berasal dari laba ditahan tidak dapat menjadi pengurang laba. Beban bunga yang dapat digunakan sebagai pengurang laba kena pajak adalah beban bunga yang muncul akibat adanya pinjaman kepada pihak ketiga atau kreditur yang tidak memiliki hubungan dengan perusahaan, sebagaimana diatur dalam UU No.36 Tahun 2008 pasal 6 ayat 1a dan pasal 18.

Temuan dalam penelitian ini sejalan dengan Ozkan (2001) yang memberikan bukti bahwa perusahaan yang memiliki kewajiban pajak tinggi akan memilih untuk berutang agar mengurangi pajak. Dengan sengajanya perusahaan berutang untuk mengurangi beban pajak maka dapat disebutkan bahwa perusahaan tersebut agresif terhadap pajak. Untuk menghindari adanya penggunaan utang 100\% maka diperhitungkan juga biaya utang atau financial distress yang disebut juga cost of bankruptcy yang menyebabkan perusahaan tidak dapat mencapai keuntungan optimal dari pembiayaan $100 \%$ utang. Cost of bankruptcy meliputi biaya langsung berupa biaya hukum dan administrasi likuidasi perusahaan termasuk di dalamnya biaya reorganisasi serta biayabiaya tidak langsung. Perusahaan juga cenderung menggunakan sumber pembiayaan internal, lalu utang dan terakhir menggunakan equity.

Lebih lanjut, hasil penelitian ini didukung oleh hasil penelitian Richardson dan Lanis (2007) yang menyatakan bahwa leverage berpengaruh negatif terhadap penghindaran pajak. Perusahaan berutang untuk mengurangi beban pajak maka dapat disebutkan bahwa perusahaan tersebut agresif terhadap pajak. Semakin tinggi rasio leverage, berarti semakin tinggi jumlah pendanaan dari utang pihak ketiga yang digunakan perusahaan dan semakin tinggi pula biaya bunga yang timbul dari utang tersebut. Biaya bunga yang semakin tinggi akan memberikan pengaruh berkurangnya beban pajak perusahaan. Semakin tinggi nilai utang perusahaan maka nilai CETR (Cash Effective Tax Rates) perusahaan akan semakin rendah. Akan tetapi hasil penelitian di atas bertolak belakang dengan hasil penelitian yang dilakukan oleh Kurniasih dan Sari (2013) yang menyimpulkan bahwa leverage tidak memiliki pengaruh yang signifikan terhadap penghindaran pajak.

Teori agensi (Jensen \& Meckling, 1976) menyatakan hubungan kontrak antara agen (manajemen suatu usaha) dan prinsipal (pemilik usaha), di mana agen melakukan tugas-tugas tertentu untuk prinsipal yang pada prinsipnya adalah memberi keuntungan yang sebesarbesarnya kepada prinsipal, sehingga agen berupaya maksimal untuk memenuhi tugasnya tersebut. Salah satu tugas agen atau pihak manajemen adalah membuat laporan keuangan, termasuk di dalamnya laporan tentang leverage perusahaan terkait penghindaran pajak. Pihak agen dapat melaporkan keadaan leverage perusahaan yang dapat menghindarkan perusahaannya dari membayar pajak selama periode waktu tertentu sehingga laba perusahaan tidak berkurang karena harus membayar pajak, hal ini adalah untuk kepentingan principal.

Hipotesis ketiga dalam penelitian ini menyatakan bahwa komposisi dewan komisaris independen berpengaruh negatif terhadap penghindaran pajak. Hasil analisis regresi dalam penelitian ini menunjukkan bahwa komposisi dewan komisaris tidak berpengaruh signifikan terhadap penghindaran pajak, sehingga hipotesis ketiga dalam penelitian ini tidak didukung. Hal ini dapat dimaknai bahwa komisaris independen yang ada pada perusahaan perbankan belum mampu 
mencegah manajemen melakukan penghindaran pajak. Besar kecilnya proporsi komisaris independen dalam jajaran dewan komisaris bank dalam penelitian ini sama saja, yaitu tidak dapat menghambat keputusan penghindaran pajak perusahaan.

Hal ini perlu menjadi perhatian karena fungsi komisaris independen sesuai Surat keputusan Direksi PT Bursa Efek Jakarta (BEJ) Nomor: Kep.315/BEJ/06-2000 adalah ditujukan dalam rangka penyelenggaraan pengelolaan perusahaan yang baik (good corporate governance). Untuk mencapai tujuan tersebut perusahaan yang tercatat di BEI wajib memiliki komisaris independen yang jumlah proporsionalnya sebanding dengan jumlah saham yang dimiliki oleh bukan pemegang saham pengendali dengan ketentuan jumlah komisaris independen sekurang-kurangnya 30\% dari jumlah seluruh anggota komisaris. Komisaris independen dapat melaksanakan fungsi monitoring untuk mendukung pengelolaan perusahaan yang baik dan menjadikan laporan keuangan lebih obyektif (Suyono, 2016). Salah satu fungsi monitoring oleh dewan komisaris independen ini adalah dengan cara melakukan pengawasan dan kontrol terhadap kebijakan-kebijakan direksi yang dianggap dapat merugikan perusahaan maupun citra perusahaan di masa depan dimana salah satunya adalah praktik penghindaran pajak.

Komisaris independen diharapkan dapat menjalankan fungsi pengawasan sebagai komisaris dan juga diharapkan dapat untuk tidak terpengaruh dengan kepentingan pemilik saham karena bersifat independen. Dengan demikian, semakin besar proporsi anggota komisaris yang bersifat independen semestinya akan mampu menghambat perusahaan untuk melakukan penghindaran pajak. Namun temuan dalam penelitian ini memberikan bukti empiris bahwa kondisi koisaris independen pada perusahaan perbankan di Indonesia belum menjalankan fungsinya secara optimal sehingga keberadaanya tidak mampu menurunkan praktik penghindaran pajak.

Temuan dalam penelitian ini sekaligus mendukung pendapat Amstrong et al. (2015) yang menyatakan bahwa dalam pengambilan proses pengambilan keputusan komisaris independen tidak mengetahui banyak mengenai internal perusahaan dan perencanaan penghindaran pajak melainkan lebih menjelaskan risiko biaya yang harus ditanggung perusahaan akibat penghindaran pajak. Hasil penelitian ini sejalan dengan hasil penelitian yang dilakukan oleh Kurniasih dan Sari (2013) yang menunjukkan bahwa komposisi dewan komisaris independen dan komite audit tidak berpengaruh terhadap penghindaran pajak. Namun hasil penelitian ini tidak sejalan dengan hasil penelitian Prakoso (2014) menunjukkan bahwa dewan komisaris independen berpengaruh negatif terhadap tax avoidance. Hasil penelitian mengandung pengertian bahwa penerapan tata kelola perusahaan yang dilihat dari segi komposisi komisaris independen dalam perusahaan perbankan belum dapat mencegah management melakukan usaha yang agresif dalam pengelolaan beban pajak perusahaan.

Hipotesis keempat dalam penelitian ini menyatakan bahwa jumlah komite audit berpengaruh negatif terhadap penghindaran pajak. Hasil analisis regresi dalam penelitian ini menunjukkan bahwa jumlah komite audit tidak berpengaruh signifikan terhadap penghindaran pajak sehingga hipotesis keempat dalam penelitian ini tidak didukung. Hasil ini menunjukkan bahwa komite audit bukanlah faktor yang dapat menentukan besar kecilnya penghindaran pajak suatu perusahaan perbankan. Ini dapat diartikan bahwa jumlah komite audit yang ada di dalam perusahaan bank baik besar atau kecil, tidak mampu mencegah adanya penghindaran pajak.

Dengan demikian temuan dalam penelitian ini membuktikan bahwa keberadaan komite audit pada perusahaan perbankan di Indonesia belum mampu menjalankan perannya secara optimal dimana komite audit memiliki 
peran membantu dewan komisaris untuk memenuhi tanggung jawab dalam memberikan pengawasan secara menyeluruh. Sejak direkomendasikan GCG di Bursa Efek Indonesia, komite audit telah menjadi komponen umum dalam struktur good corporate governance perusahaan publik. Pada umumnya, komite ini berfungsi sebagai pengawas proses pembuatan laporan keuangan dan pengawasan internal, karena $\mathrm{BEI}$ mengharuskan semua emiten untuk membentuk dan memiliki komite audit yang diketuai oleh komisaris independen (Suyono, 2016).

Temuan dalam penelitian ini sejalan dengan Prakoso (2014) dan Kurniasih dan Sari (2013) yang hasilnya menunjukkan bahwa komite audit tidak berpengaruh terhadap tax avoidance. Hal ini berarti bahwa keberadaan komite audit yang fungsinya untuk meningkatkan integritas dan kredibilitas pelaporan keuangan tidak dapat berjalan dengan baik apabila tidak ada dukungan dari seluruh elemen dari dalam perusahaan. Berdasarkan hasil tersebut komite audit diindikasikan dalam pelaksanaannya kurang didukung oleh elemen-elemen lain yang berada didalam perusahaan, sehingga menyebabkan komite audit gagal melakukan pengawasan yang baik dan cenderung netral.

Hipotesis kelima dalam penelitian ini menyatakan bahwa bahwa kompensasi rugi fiskal berpengaruh negatif terhadap penghindaran pajak, sedangkan hasil analisis regresi sesuai dengan pernyataan tersebut, sehingga hipotesis kelima didukung. Hal ini menunjukkan bahwa kompensasi rugi fiskal merupakan faktor yang dapat menentukan besar kecilnya penghindaran pajak di perusahaan perbankan yang diteliti. Ini dapat terjadi karena penghindaran pajak tetap dilakukan baik pada perusahaan yang memiliki kompensasi rugi fiskal maupun yang tidak memiliki kompensasi rugi fiskal. Pengaruh yang negatif, mengandung arti bahwa semakin tinggi kompensasi rugi fiskal suatu bank maka akan semakin rendah nilai penghindaran pajak yang dilakukan di bank tersebut.

Hasil penelitian ini menggambarkan keadaan perusahaan perbankan yang terdaftar di BEI yang diteliti, dimana perusahaan yang mengalami kerugian mengungkapkan kompensasi rugi fiskal sehingga laba dikompensasikan selama lima tahun ke depan untuk mengurangi jumlah kompensasi kerugian tersebut yang berakibat selama lima tahun ke depan perusahaan terhindar dari beban pajak. Hasil penelitian ini sejalan dengan hasil penelitian yang dilakukan oleh Kurniasih dan Sari (2013) yang menemukan bahwa perusahaan yang merugi dalam satu periode akuntansi diberikan keringanan dalam membayar pajaknya. Kerugian fiskal suatu tahun pajak dapat dikompensasikan dengan penghasilan mulai tahun pajak berikutnya berturut - turut sampai dengan lima tahun. Akibatnya, selama lima tahun tersebut, perusahaan akan terhindar dari beban pajak, karena laba kena pajak akan digunakan untuk mengurangi jumlah kompensasi kerugian Kompensasi rugi fiskal dapat dimanfaatkan oleh pihak manajemen dalam melakukan tindakan penghindaran pajak. Sedangkan hasil penelitian Prakosa (2014) menunjukkan bahwa kompensasi rugi fiskal tidak berpengaruh terhadap penghindaran pajak.

\section{PENUTUP}

Penelitian ini bermaksud menganalisis pengaruh profitabilitas, leverage, komposisi dewan komisaris, komite audit, dan kompensasi rugi fiskan sebagai variable independen dengan ukuran perusahaan sebagai variable control terhadap penghindaran pajak pada perbankan konvensional yang tercatat di Bursa Efek Indonesia. Dengan menggunakan pendekatan purposive sampling, penelitian ini mendapatkan 30 perusahaan sebagai sampel selama periode 2011-2015, sehingga total oabservasi adalah 150 observasi. Hasil analsis dalam penelitian ini menyimpulkan bahwa profitabilitas berpengaruh 
positif terhadap penghindaran pajak, leverage dan kompensasi rugi fiskal berpengaruh negatif terhadap penghindaran pajak, serta komposisi komisaris independen dan jumlah komite audit tidak berpengaruh terhadap penghindaran pajak pada perusahaan perbankan konvensional di Bursa Efek Indonesia periode 2011-2015.

Implikasi teoritis yang dapat diperoleh dari penelitian ini adalah bahwa hasil penelitian ini mampu menambah wawasan dan pengetahuan bagi perkembangan ilmu pengetahuan dalam bidang akuntansi keuangan yang berhubungan dengan lingkup perusahaan perbankan. Sedangkan secara praktis, penelitian ini bisa digunakan sebagai dasar Bursa EFek Indonesia dan Otoritas Jasa Keuangan untuk mengevaluasi kembali keberadaan komisari independen dan komite audit sebagai kerangka good corporate governance yang ternyata belum mampu menjalankan perannya secara optimal sehingga keberadaan dua instrument tersebut belum mampu menurunkan praktik penghindaran pajak pada perusahaan perbankan yang tercatat di Bursa Efek Indonesia.

Bagi peneliti selanjutnya yang tertarik meneliti tema yang sama, diharapkan mampu menambah sampel penelitian misalnya menambah kategori perusahaan yang terdaftar di BEl. Serta untuk peneliti selanjutnya yang ingin meneliti tema yang sama agar dapat mempertimbangkan faktor-faktor lain yang mempengaruhi penghindaran pajak seperti kualitas audit. Untuk metode pengukuran penghindaran pajak peneliti berharap peneliti selanjutnya dapat menggunakan model pengukuran lainnya seperti Effective Tax Rate (ETR), Cash Effective Tax Rate (CETR), dan sebagainya.

\section{REFERENSI:}

Annisa, N.A., dan Kurniasih, L. 2012. Pengaruh Corporate Governance terhadap Tax Avoidance. Jurnal Akuntansi dan Auditing, 8(2), 95-189.

Armstrong, C., Blouin, J., Jagolinzer, A., and Larcker, D.F. 2015. Corporate governance, Incentives, and Tax Avoidance. Journal of Accounting and Economics.60(1), 1-17.

Budiman, J., dan Setiyono. 2012. Pengaruh Karakteristik Eksekutif terhadap Penghindaran Pajak (Tax Avoidance). Prosiding Simposium Nasional Akuntansi XV, Banjarmasin.

Chen, S., Chen, X., Cheng, Q., and Shevlin, T. 2010. Are Family Firms More Tax Aggresive than Non-Family Firms?. Journal of Financial Economics, 95, 41-61.

Darussalam, S.D. 2008. Konsep dan Aplikasi Cross-Border Transfer Pricing untuk Tujuan Perpajakan. PT. Dimensi Internasional Tax, Jakarta.

Desai, M., and Dharmapala, D. 2006. Corporate Tax Avoidance and High-Powered Incentives. Journal of Financial Economics 79(1),145-179.

Dyreng, S.D., Hanlon, M., and Maydew, E.L. 2008. Long-Run Corporate Tax Avoidance. The Accounting Review, 83(1), 61-82.

Farooque, O.A., Suyono, E., and Rosita, U. 2014. Link Between Market Return, Good Governance, and Earnings Management: Emerging Market Perspective. Corporate Ownership and Control, 11(2), 192-211.

Jensen, M.C,. and Meckling, W.H. 1976. Theory of the Firm: Managerial Behavior, Agency Costs and Ownership Structure . Journal of Financial Economics, 3(4), 305-360.

Kurniasih, T., dan Sari, M.R. 2013. Pengaruh Return on Assets, Leverage, Corporate Governance, Ukuran Perusahaan dan Kompensasi Rugi Fiskal Pada Tax Avoidance. Buletin Studi Ekonomi, 18(1),58-65.

Kusuma, H. 2014. Kasus Pajak BCA Gerbang KPK Selidiki Perbankan RI. Dapat diakses di: http://economy.okezone.com/read/2014/04/25/457/975953/kasus-pajak-bca-gerbang-kpk-selidikiperbankan-ri. 
Lestari, M.I., dan Sugiharto, T. 2007. Kinerja Bank Devisa dan Bank Non Devisa dan Faktor-Faktor Yang Mempengaruhinya. Prosiding PESAT (Psikologi, Ekonomi, Sastra, Arsitek dan Sipil). Fakultas Ekonomi, Universitas Gunadarma.

Liao, Y.H., and Fu, Q.R. 2015. Research on The Correlation Between Book-Tax Difference and Earnings Management. Proceeding of International Conference on Education Technology and Economic Management (ICETEM 2015), Beijing, China.

Maharani, C., dan Suardana, At. 2014. Pengaruh Corporate Governance, Profitabilitas dan Karakteristik Eksekutif pada Tax Avoidance Perusahaan Manufaktur. E-jurnal Akuntansi Universitas Udayana, 9(2), 525-539.

Ozkan, A. 2001. Determinants of Capital Structure and Adjustment to Long Run Target: Evidence from UK Company Panel Data. Journal of Bussiness Finance and Accounting, 28 (1) and (2).

Prakosa, K.B. 2014. Pengaruh Profitabilitas, Kepemilikan Keluarga dan Corporate Governance Terhadap Penghindaran Pajak di Indonesia. Prosiding SNA 17, Mataram.

Pratama, Adi. 2006. Sinopsis Teori Regulasi: Memahami dan Membumikan Teori Regulasi. http://economic regulation.blogspot.com/2006/11/ memahami-dan-membumikan-teori-regulasi_08.html. Diakses tanggal 29 Juli 2015.

Rachmawati, A., dan Triatmoko, H. 2007. Analisis Faktor-Faktor yang Mempengaruhi Kualitas Laba dan Nilai Perusahaan. Prosiding Simposium Nasional Akuntansi (SNA) X. Makassar.

Richardson, G., and Lanis, R. 2007. Determinants of Variability in Corporate Effective Tax Rates and Tax Reform: Evidence From Australia. Journal of Accounting and Public Policy, 26, 689-704.

Rinaldi dan Cheisviyanny, C. 2015. Pengaruh Profitabilitas, Ukuran Perusahaan Dan Kompensasi Rugi Fiskal Terhadap Tax Avoidance. Prosiding Seminar Nasional Ekonomi Manajemen Dan Akuntansi (Snema), Fakultas Ekonomi Universitas Negeri Padang.

Sartori, N. 2008. Effect of Strategic Tax Behaviors on Corporate Governance. Available on: www.ssrn.com.

Surat Keputusan Direksi PT Bursa Efek Jakarta (BEJ) Nomor: Kep 315/ BEJ/06-2000 Perihal Peraturan No I-A, tentang Pencatatan Saham dan Efek bersifat Ekuitas selain Saham yang diterbitkan oleh Perusahaan Tercatat.

Suyono, E. (2016). Family Controlled Firm, Governance Mechanisms and Corporate Performance : Evidence from Indonesia. Journal of Economics, Business, and Accountancy Ventura, 19 (1), 111 - 124.

Suyono, E., and Farooque, O. 2018. Do Governance Mechanisms Deter Earnings Management and Promote Corporate Social Responsibility?. Accounting Research Journal, Vol. 31 No. 3. 479-495.

Swingly, C., dan Sukartha, I.M. 2015. Pengaruh Karakter Eksekutif, Komite Audit, Ukuran Perusahaan, Leverage, dan Sales Growth pada Tax Avoidance. E-Jurnal Akuntansi Universitas Udayana, 10(1), 47-62.

Undang-Undang No.17 tahun 2000 tentang Pajak Penghasilan.

Undang-Undang No. 36 tahun 2008 tentang Pajak Penghasilan.

Watts, R., and Zimmerman, J. 1986. Positive Accounting Theory. Englewood Cliffs, New Jersey: Prentice-Hall.

Widihartanto, S. 2011.Membangun Kepatuhan Pajak Melalui Regulasi Responsif (Bagian I). http://mofilink.com/revenuetax/membangun-kepatuhan-pajak-melalui-regulasi-yang-responsif/gian. 